\title{
PENGARUH TAT, $C R$, ROA, DAN PER TERHADAP HARGA SAHAM PROPERTI DAN REAL ESTATE DI BEI
}

\author{
Ni Ketut Nadila Suryasari ${ }^{1}$ \\ Luh Gede Sri Artini \\ ${ }^{2}$ Fakultas Ekonomi dan Bisnis Universitas Udayana, Bali, Indonesia \\ email: nadila.suryasari@gmail.com
}

\begin{abstract}
ABSTRAK
Investor menilai suatu saham dengan menggunakan analisis fundamental terhadap variabel yang diperkirakan akan mempengaruhi harga suatu saham. Penelitian ini bertujuan memberikan bukti empiris bahwa Total Asset Turnover (TAT), Current Ratio $(C R)$, Return On Asset (ROA), dan Price Earning Ratio (PER) berpengaruh terhadap harga saham. Penelitian ini dilakukan pada perusahaan Properti dan Real Estate yang terdaftar di BEI periode pengamatan 2016-2018 dengan menggunakan metode purposive sampling. Terdapat jumlah sampel sebanyak 36 perusahaan. Pengumpulan data dilakukan dengan metode observasi non partisipan dan teknik analisis data menggunakan teknik analisis regresi linier berganda. Berdasarkan hasil analisis ditemukan bahwa TAT, CR, ROA, dan $P E R$ secara simultan berpengaruh terhadap harga saham. Secara parsial TAT dan $C R$ tidak berpengaruh terhadap harga saham. Hal tersebut memberi arti bahwa investor dalam melakukan investasi tidak memperhatikan rasio TAT dan $C R$. Sedangkan ROA dan PER secara parsial berpengaruh positif dan signifikan terhadap harga saham. Hal tersebut menunjukkan bahwa investor memperhatikan rasio $R O A$ dan $P E R$ dalam berinvestasi saham. Semakin tinggi nilai $R O A$ dan $P E R$ maka semakin tinggi pula minat investor untuk menanamkan modalnya pada perusahaan tersebut sehingga harga saham perusahaan pun akan mengalami kenaikan.
\end{abstract}

Kata kunci: total asset turnover, current ratio, return on asset, price earning ratio, harga saham

\begin{abstract}
Investors value a stock using fundamental analysis of variables that are expected to affect the price of a stock. This study aims to provide empirical evidence that Total Assets Turnover (TAT), Current Ratio (CR), Return On Assets (ROA), and Price Earning Ratio (PER) affect the stock price. This research was conducted at property and real estate company listed on IDX for the 2016-2018 observation period using a purposive sampling method. There are total sample of 36 companies. Data collection was performed using nonparticipant observation methods and data analysis techniques using multiple linear regression analysis techniques. Based on the results of the analysis found that TAT, CR, ROA, and PER simultaneously affect the stock prices. Partially TAT and CR have no effect on stock prices. This means that investors in investing do not pay attention to the ratio of TAT and CR. Whereas ROA and PER partially have a positive and significant effect on stock prices. This shows that investors pay attention to the ratio of ROA and PER in investing in shares. The higher value of ROA and PER, the higher the interest of investors to invest their capital in the company so that the company's stock price will increase.

Keywords: total asset turnover, current ratio, return on assets, price earnings ratio, stock prices
\end{abstract}




\section{PENDAHULUAN}

Investasi dalam pasar modal kini menjadi aktivitas alternatif untuk mendapatkan keuntungan sebagai pemenuhan kebutuhan seseorang. Investasi adalah penggunaan sejumlah dana atau sumber daya lainnya saat ini, untuk memperoleh sejumlah keuntungan di masa yang akan datang (Tandelilin, 2014:2). Salah satu instrumen investasi yang populer di pasar modal adalah saham. Perusahaan mengeluarkan saham untuk pemenuhan kebutuhan pendanaannya, sementara pemodal membeli saham untuk mendapatkan keuntungan dimasa yang akan datang berupa dividen atau capital gain. Dividen adalah sebagian keuntungan perusahaan yang dibagikan kepada pemegang saham, sedangkan capital gain adalah selisih lebih antara harga beli dengan harga jual saham. Emiten yang dapat menghasilkan laba yang tinggi akan meningkatkan return yang diperoleh investor yang tercermin dari harga saham tersebut.

Harga saham adalah harga yang terbentuk melalui mekanisme permintaan dan penawaran di pasar modal (Sartono, 2014:70). Harga saham juga dapat didefinisikan sebagai harga yang dibentuk dari interaksi antara para penjual dan pembeli saham yang dilatarbelakangi oleh harapan investor terhadap keuntungan perusahaan. Harga saham merupakan salah satu indikator keberhasilan pengelolaan perusahaan, jika harga saham suatu perusahaan selalu mengalami kenaikan, maka investor atau calon investor menilai bahwa perusahaan berhasil dalam mengelola usahanya. Kepercayaan investor atau calon investor sangat bermanfaat bagi perusahaan, karena semakin banyak orang yang percaya terhadap perusahaan maka keinginan untuk berinvestasi pada perusahaan semakin kuat. Banyaknya permintaan terhadap saham suatu perusahaan maka dapat menaikkan harga saham tersebut, jika harga saham yang tinggi dapat dipertahankan maka kepercayaan investor atau calon investor terhadap perusahaan juga semakin tinggi dan hal ini dapat menaikkan nilai perusahaan. Apabila perusahaan mengalami kecenderungan penurunan harga saham investor pun enggan untuk membeli saham perusahaan tersebut, sehingga akan mengakibatkan penawaran lebih besar dari permintaan yang akan berujung pada menurunnya nilai perusahaan dimata investor atau calon investor.

Harga saham terus berfluktuasi tergantung dari prospek perusahaan di masa yang akan datang serta jumlah permintaan dan penawaran atas saham tersebut (Dewi \& Artini, 2016). Berdasarkan hal tersebut, maka penting sekali bagi pihak manajemen perusahaan untuk selalu menjaga agar harga sahamnya selalu mengalami kenaikan. Tingginya harga saham akan berdampak terhadap kemakmuran para pemegang saham, sekaligus dapat membuat citra perusahaan semakin baik dimata masyarakat, baik investor maupun calon investor yang ingin menanamkan modalnya di perusahaan tersebut. Bagi investor, keputusan investasi dalam suatu saham harus didahului oleh suatu proses analisis terhadap variabel yang diperkirakan akan mempengaruhi harga suatu saham. Investor dalam melakukan investasi membutuhkan berbagai informasi untuk memprediksikan hasil investasinya di masa yang akan datang. Investor menggunakan dua pendekatan dasar dalam melakukan analisis dalam memilih saham, yaitu analisis teknikal dan analisis fundamental. Analisis teknikal adalah teknik untuk memprediksi arah pergerakan harga saham dan indikator pasar saham lainnya 
berdasarkan pada data pasar historis seperti informasi harga dan volume (Tandelilin, 2014:392). Analisis teknikal bertentangan dengan pemikiran analisis fundamental, analisis teknikal percaya bahwa harga masa lalu memiliki kemampuan untuk "memperbaiki" pergerakan harga saat ini, dan saat ini harga yang bergerak merupakan sikap investor ke arah itu. Analisis teknikal jarang melihat atau memperhatikan pada kinerja ekonomi, melainkan lebih tertarik untuk mengetahui tentang kinerja pergerakan harga.

Penilaian terhadap harga saham dilakukan investor tidak hanya dengan menggunakan analisis teknikal, tetapi juga perlu melakukan analisis secara fundamental. Analisis fundamental adalah analisis untuk menghitung nilai intrinsik saham dengan menggunakan data keuangan perusahaan (Hartono, 2017:209). Analisis fundamental percaya pada konsep investasi dengan berpegangan pada saham yang bagus untuk jangka panjang serta dapat memperoleh dividen dari perusahaan tersebut. Penelitian ini memilih menggunakan analisis fundamental karena analisis fundamental merupakan langkah awal dalam menilai suatu perusahaan sebagai keputusan investasi seseorang. Gusni (2015) menyatakan bahwa analisis fundamental merupakan salah satu cara melakukan penilaian saham dengan mempelajari atau mengamati berbagai indikator terkait kondisi makro/ekonomi, industri, dan analisis perusahaan. Analisis terhadap kondisi makro menilai pertumbuhan ekonomi saat ini dan masa yang akan datang dengan menggunakan data ekonomi. Analisis industri berfokus pada kinerja berbagai industri untuk mengetahui prospeknya pada masa yang akan datang sedangkan analisis perusahaan adalah analisis mengenai data keuangan perusahaan. Analisis fundamental mengkombinasikan analisis kondisi ekonomi/makro ekonomi, industri, dan perusahaan untuk mendapatkan nilai saham yang sebenarnya yang disebut dengan nilai intrinsik perusahaan. Nilai intrinsik ini nantinya akan dibandingkan dengan nilai pasar saham (market value) untuk mengetahui apakah harga saham perusahaan tersebut fair, overvalued, atau undervalued (Tandelilin, 2014:363). Harga saham yang tidak sesuai dengan kondisi perusahaan yang sesungguhnya dapat diuji menggunakan analisis fundamental.

Penelitian ini menganalisis faktor-faktor yang mempengaruhi harga saham, yaitu analisis fundamental perusahaan. Analisis fundamental perusahaan digunakan dalam penelitian ini untuk mengetahui apakah saham suatu perusahaan layak dijadikan pilihan investasi (Tandelilin, 2014:363). Analisis fundamental perusahaan dapat dilihat dari kinerja keuangan perusahaan. Alasan mengapa menganalisis kinerja keuangan adalah karena dengan menggunakan kinerja keuangan dapat diketahui kondisi keuangan perusahaan dari berbagai aspek, dimana informasi tersebut sangat berguna bagi para investor yang akan menanamkan dananya dalam suatu perusahaan. Menganalisis kinerja keuangan dapat dilakukan dengan merubah data laporan keuangan menjadi rasio keuangan. Menganalisis laporan keuangan sangat bermanfaat dalam memahami dan memprediksi kinerja keuangan suatu perusahaan, sementara rasio keuangan adalah alat analisis perencanaan keuangan yang sederhana dan praktis (Tamuntuan, 2015). Analisis fundamental memiliki beberapa rasio keuangan yang dapat mencerminkan kondisi keuangan dan kinerja suatu perusahaan. Investor 
menggunakan rasio keuangan sebagai faktor pertimbangan dalam mengambil keputusan investasi karena rasio keuangan bersifat lebih fleksibel dan sederhana sehingga mampu memberi jawaban yang lebih akurat dalam keputusan investasi yang akan dilakukan. Rasio keuangan yang digunakan dalam penelitian ini adalah adalah Total Assets Turnover (TAT), Current Ratio (CR), Return On Assets (ROA), dan Price Earning Ratio (PER).

TAT merupakan salah satu bentuk dari rasio aktivitas, yang digunakan untuk mengukur kemampuan dana yang tertanam dalam keseluruhan aktiva yang berputar pada suatu periode atau kemampuan modal yang diinvestasikan untuk menghasilkan pendapatan. TAT menunjukkan tingkat efisiensi penggunaan keseluruhan aset perusahaan dalam menghasilkan volume penjualan tertentu. Tingginya rasio $T A T$, berarti semakin efisien penggunaan keseluruhan aset dalam menghasilkan penjualan/pendapatan. TAT dinilai penting bagi para kreditur dan pemilik perusahaan, karena akan menunjukkan efisien tidaknya penggunaan seluruh aset dalam suatu perusahaan. Penelitian yang dilakukan oleh Herawati \& Putra (2018) menemukan hasil bahwa TAT berpengaruh positif signifikan terhadap harga saham perusahaan sektor food and beverages di Bursa Efek Indonesia untuk periode 2012-2015. Nur'aidawati (2018) dan Mulyono et al. (2018) juga menemukan hasil yang sama bahwa TAT berpengaruh positif dan signifikan terhadap harga saham. Penelitian dengan hasil yang berbeda dilakukan oleh Nugraha \& Sudaryanto (2016) yang menemukan bahwa TAT berpengaruh negatif terhadap harga saham perusahaan Industri Dasar dan Kimia yang terdaftar di BEI periode 2010-2014. Ermaya \& Nugraha (2018) menemukan hasil penelitian yang sama bahwa TAT memiliki hubungan negatif dan signifikan terhadap harga saham pada perusahaan Industri Barang Konsumsi yang terdaftar di BEI periode 2014-2015. Penelitian yang dilakukan oleh Firmansyah (2017) pada Perusahaan Manufaktur di BEI periode 2010 sampai dengan 2014 menemukan hasil yang sama bahwa TAT tidak berpengaruh signifikan terhadap Harga Saham.

Rasio keuangan lainnya adalah rasio likuiditas. Rasio likuiditas digunakan untuk mengukur kemampuan perusahaan untuk memenuhi kewajiban jangka pendeknya. Rasio likuiditas yang utama adalah rasio lancar atau current ratio (Brigham \& Houston, 2015:134). CR mengukur kemampuan aktiva lancar untuk membayar utang saat ini. Rasio ini dihitung dengan membagi aktiva lancar dengan kewajiban lancar dimana hal tersebut menunjukkan bagaimana kewajiban lancar ditutupi dengan aset yang akan dikonversi menjadi uang tunai dalam waktu dekat. Aktiva lancar meliputi kas, surat berharga yang dapat diperdagangkan, piutang, dan persediaan. Kewajiban lancar terdiri dari hutang, wesel tagih jangka pendek, hutang jangka panjang, pajak dan gaji yang masih harus dibayar (Brigham \& Houston, 2015). Penelitian yang dilakukan oleh Herawati \& Putra (2018) menemukan hasil bahwa $C R$ berpengaruh positif terhadap harga saham perusahaan sektor food and beverages di Bursa Efek Indonesia untuk periode 2012-2015. Martha \& Meilin (2018) juga menemukan hasil yang sama bahwa $C R$ berpengaruh positif signifikan terhadap harga saham. Penelitian yang dilakukan Dadrasmoghadam \& Akbari (2015) menemukan hasil bahwa $C R$ tidak berpengaruh terhadap harga saham. Penelitian dengan hasil yang berbeda 
dilakukan Sitorus \& Elinarty (2017) menemukan hasil bahwa $C R$ berpengaruh negatif terhadap harga saham sektor perbankan di Bursa Efek Indonesia. Nursiam \& Rahayu (2019) menemukan hasil penelitian bahwa $C R$ berpengaruh negatif terhadap harga saham. Pratama dkk. (2019) juga menemukan hasil penelitian yang menunjukkan bahwa $C R$ berpengaruh negatif dan signifikan terhadap harga saham perusahaan Jakarta Islamic Index yang terdaftar di BEI tahun 2014-2017.

Pertumbuhan profitabilitas merupakan indikator penting untuk menilai prospek perusahaan dimasa mendatang. Indikator ini penting diperhatikan untuk mengetahui investasi yang akan dilakukan investor dalam memberikan return yang sesuai dengan tingkat yang diisyaratkan investor. Salah satu rasio profitabilitas yang digunakan untuk mengukur kemampuan perusahaan dalam menghasilkan laba bersih, yaitu ROA. Brigham \& Houston (2015:148) mengatakan bahwa ROA mengukur seberapa besar perusahaan dalam meningkatkan laba bersihnya dengan menggunakan total aset yang dimiliki perusahaan. ROA yang besar menunjukkan bahwa keuntungan/laba yang dicapai perusahaan semakin besar, sehingga permintaan akan saham meningkat yang nantinya akan dapat meningkatkan harga saham perusahaan tersebut. Penelitian yang dilakukan oleh Mogonta \& Pandowo (2016), menemukan hasil bahwa ROA memiliki pengaruh positif dan signifikan terhadap harga saham pada perusahaan pertambangan yang terdaftar di indeks LQ-45 di Bursa Efek Indonesia periode 2011-2015. Hasil yang sama ditemukan oleh Dadrasmoghadam \& Akbari (2015) dan Herawati \& Putra (2018) bahwa ROA berpengaruh positif dan signifikan terhadap harga saham. Penelitian yang dilakukan Hadi \& Nurhayati (2018) menemukan hasil bahwa ROA berpengaruh negatif terhadap harga saham. Penelitian yang dilakukan Ayudia (2017), menemukan hasil yang sama bahwa ROA berpengaruh negatif signifikan terhadap harga saham. Idawati \& Wahyudi (2015) juga menemukan hasil bahwa ROA berpengaruh negatif dan signifikan terhadap harga saham perusahaan Pertambangan Batubara yang terdaftar di BEI.

Rasio keuangan yang tidak kalah penting untuk mengukur kinerja perusahaan adalah rasio pasar. Rasio pasar yang digunakan dalam penelitian ini yaitu PER. PER adalah rasio atau perbandingan antara harga saham terhadap earning perusahaan, menurut Tandelilin (2014:320). PER yang tinggi menunjukkan bahwa investor bersedia untuk membayar dengan harga saham premium atau dengan harga di atas harga pasar. Bassey (2016) menemukan hasil bahwa $P E R$ berpengaruh positif signifikan terhadap harga saham pada perusahaan minyak dan gas di Bursa Efek Nigeria sesuai dengan pendapat Astuty (2017) yang juga menemukan pengaruh positif $P E R$ terhadap harga saham. Penelitian dengan hasil yang berbeda dilakukan Lestari \& Suryantini (2019) juga menemukan hasil bahwa $P E R$ berpengaruh negatif dan signifikan terhadap harga saham perusahaan Farmasi di BEI. Hasil penelitian yang dilakukan Warrad (2017) menemukan hasil bahwa PER tidak berpengaruh signifikan terhadap harga saham pada bank di Jordania. Arshad et al. (2015) melakukan penelitian pada Bank Komersial yang terdaftar di Bursa Efek Karachi Pakistan periode 2007-2013 dan menemukan hasil yang sama bahwa PER tidak berpengaruh signifikan terhadap harga saham.

Penelitian ini menggunakan perusahaan Properti dan Real Estate yang terdaftar di Bursa Efek Indonesia karena perusahaan Properti dan Real Estate 
merupakan salah satu sektor terpenting di suatu Negara. Pentingnya perusahaan Properti dan Real Estate dapat dijadikan indikator untuk menganalisis kesehatan ekonomi suatu Negara (Azhari dkk, 2016). Industri properti dan real estate merupakan salah satu sektor yang memberikan tanda jatuh atau sedang bangunnya perekonomian suatu Negara. Hal tersebut menandakan bahwa semakin banyak perusahaan yang bergerak di bidang sektor properti dan real estate mengindikasikan semakin berkembangnya perekonomian di Indonesia.

Sektor properti sebagai salah satu instrumen usaha biasanya dipilih investor karena properti dan real estate merupakan salah satu alternatif investasi yang diminati investor dimana investasi di sektor ini merupakan investasi jangka panjang dan properti merupakan aktiva multiguna yang dapat digunakan oleh perusahaan sebagai jaminan. Perkembangan perusahaan properti dan real estate tentu saja akan menarik minat investor dikarenakan kenaikan harga tanah dan bangunan yang cenderung naik, supply tanah bersifat tetap sedangkan demand akan selalu bertambah besar seiring dengan pertambahan jumlah penduduk serta bertambahnya kebutuhan manusia akan tempat tinggal, perkantoran, pusat perbelanjaan, dan lain-lain. Apabila dilihat dari harga sahamnya, perusahaan Properti dan Real Estate dari tahun ke tahun mengalami penurunan. Berikut adalah harga saham perusahaan Properti dan Real Estate tahun 2016 sampai tahun 2018.

Tabel 1.

Data Pergerakan Harga Saham Perusahaan Properti dan Real Estate Tahun 2016-2018

\begin{tabular}{ccc}
\hline No & Tahun & Harga Saham $(\mathbf{R p})$ \\
\hline 1 & 2016 & 517,81 \\
2 & 2017 & 498,71 \\
3 & 2018 & 459,15 \\
\hline
\end{tabular}

Sumber: https://finance.yahoo.com, 2019

Berdasarkan Tabel 1. dapat dilihat bahwa harga saham perusahaan Properti dan Real Estate pada tahun 2016 sebesar 517,81 rupiah dan mengalami penurunan secara terus-menerus sampai tahun 2018. Penurunan harga saham ini menjadi menarik diteliti karena perkembangan perusahaan Properti dan Real Estate merupakan salah satu indikator dari pertumbuhan ekonomi suatu negara. Perusahaan yang bergerak pada bidang Properti dan Real Estate akan terus mengalami perkembangan karena seiring meningkatnya jumlah penduduk di Indonesia. Perusahaan Properti dan Real Estate juga banyak melakukan kegiatan investasi. Seperti diketahui bahwa harga properti di tanah air dari tahun ke tahun semakin meningkat. Harga properti yang semakin meningkat setiap tahunnya akan meningkatkan peluang keuntungan bagi investor yang menginvestasikan dananya dalam bisnis properti namun, pada kenyataan harga saham pada perusahaan properti cenderung menurun.

TAT merupakan perbandingan antara penjualan dengan total aset. Semakin tinggi rasio ini semakin efisien perusahaan-perusahaan menggunakan dananya untuk masing-masing aktiva perusahaan (Wiagustini, 2014:86). Nilai TAT yang tinggi mengindikasikan efektivitas suatu perusahaan semakin baik, sehingga 
mampu menarik minat investor untuk berinvestasi pada perusahaan tersebut yang akhirnya meningkatkan harga saham perusahaan (Nugraha \& Sudaryanto, 2016).

Teori tersebut didukung oleh penelitian yang dilakukan Herawati \& Putra (2018) dan Nur'aidawati (2018), yang menunjukkan bahwa TAT berpengaruh positif dan signifikan terhadap harga saham. Hasil penelitian yang sama dilakukan oleh Karjono \& Wijaya (2017) dan Rani \& Diantini (2015) yang menemukan bahwa TAT memiliki pengaruh yang positif dan signifikan terhadap harga saham. Mulyono et al. (2018) menemukan hasil yang sama yaitu TAT berpengaruh positif dan signifikan terhadap harga saham. Berdasarkan atas kajian teori serta hasil penelitian sebelumnya, maka dirumuskan hipotesis sebagai berikut:

$\mathrm{H}_{1}$ : Total Asset Turnover (TAT) berpengaruh positif dan signifikan terhadap harga saham

$C R$ merupakan rasio likuiditas yang umum digunakan untuk adalah rasio yang digunakan untuk mengukur tingkat likuiditas perusahaan. $C R$ menunjukkan sejauh mana aktiva lancar menutupi kewajiban-kewajiban lancar. Semakin tinggi $C R$ berarti semakin besar kemampuan perusahaan untuk memenuhi kewajiban finansial jangka pendeknya (Sartono, 2014:116). Hal ini menunjukkan bahwa perusahaan dinilai investor memiliki kemampuan untuk melunasi kewajibankewajiban jangka pendeknya, sehingga dapat meningkatkan permintaan saham perusahaan tersebut (Hanafi \& Halim, 2016:108).

Teori ini didukung dengan penelitian yang dilakukan Purnama \& Purbawangsa (2017) dan Herawati \& Putra (2018) menunjukkan bahwa $C R$ berpengaruh positif dan signifkan terhadap harga saham. Hasil penelitian yang sama dilakukan oleh Martha \& Meilin (2018) serta Dadrasmoghadam \& Akbari (2015) yang menunjukkan bahwa $C R$ memiliki pengaruh yang positif dan signifikan terhadap harga saham. Penelitian yang dilakukan oleh Rahayu \& Dana (2016) menunjukkan hasil yang sama yaitu $C R$ berpengaruh positif dan signifikan terhadap harga saham. Berdasarkan atas kajian teori serta hasil penelitian sebelumnya, maka dirumuskan hipotesis sebagai berikut:

$\mathrm{H}_{2}$ : Current Ratio $(C R)$ berpengaruh positif dan signifikan terhadap harga saham

Brigham \& Houston (2015:148) mendefinisikan ROA adalah salah satu rasio profitabilitas yang mengukur kemampuan perusahaan untuk meningkatkan laba bersihnya dengan menggunakan seluruh aktiva yang dimiliki. Semakin besar ROA, maka semakin baik karena tingkat keuntungan yang dihasilkan perusahaan dari pengelolaan asetnya semakin besar, dengan pengelolaan aset yang semakin efisien maka tingkat kepercayaan investor terhadap perusahaan akan meningkat yang nantinya akan meningkatkan harga saham (Harahap, 2015:134). ROA yang positif menunjukan jumlah aset perusahaan yang digunakan mampu memberikan keuntungan bagi perusahaan, sedangkan $R O A$ yang negatif memberikan arti bahwa penggunaan total aset perusahaan tidak mampu memberikan keuntungan bagi perusahaan itu sendiri.

Teori ROA tersebut didukung oleh penelitian yang dilakukan oleh Mogonta \& Pandowo (2016), menemukan hasil bahwa ROA memiliki pengaruh positif dan signifikan terhadap harga saham pada perusahaan pertambangan yang terdaftar di indeks LQ-45 di Bursa Efek Indonesia periode 2011-2015. Hasil penelitian yang sama dilakukan oleh Fauza \& Mustanda (2016) dan Manoppo (2015) menemukan 
bahwa ROA memiliki pengaruh yang positif dan signifikan terhadap harga saham. Hasil penelitian yang sama ditemukan oleh Zulkarnaen et al. (2016) dan Prayogo \& Lestari (2018), bahwa ROA berpengaruh positif dan signifikan terhadap harga saham. Berdasarkan atas kajian teori serta hasil penelitian sebelumnya, maka dirumuskan hipotesis sebagai berikut:

$\mathrm{H}_{3}$ : Return On Asset (ROA) berpengaruh positif dan signifikan terhadap harga saham

PER menggambarkan rasio atau perbandingan harga saham terhadap pendapatan perusahaan. PER mengindikasikan besarnya dana yang dikeluarkan oleh investor untuk memperoleh setiap rupiah laba perusahaan (Tandelilin, 2014:375). Rasio ini menggambarkan kesediaan investor membayar suatu jumlah tertentu untuk setiap rupiah perolehan laba perusahaan. Semakin tinggi PER maka semakin tinggi pengakuan pasar terhadap posisi finansial perusahaan, dimana hal ini menarik minat investor terhadap saham perusahaan tersebut sehingga harga saham semakin mahal (Wiagustini, 2014:86).

Teori PER tersebut didukung oleh penelitian yang dilakukan oleh Astutik et al (2014) menunjukkan bahwa PER berpengaruh positif dan signifikan terhadap harga saham perusahaan Manufaktur yang terdaftar di BEI. Hasil penelitian yang sama dilakukan oleh Astuty (2017) dan Bassey (2016) yang menunjukkan bahwa PER berpengaruh positif dan signifikan terhadap harga saham. Penelitian yang dilakukan Rahmadewi \& Abundanti (2018) dan Sharif et al (2015) juga menunjukkan hasil yang sama yaitu $P E R$ berpengaruh positif dan signifikan terhadap harga saham. Berdasarkan atas kajian teori serta hasil penelitian sebelumnya, maka dirumuskan hipotesis sebagai berikut:

$\mathrm{H}_{4}$ : Price Earning Ratio (PER) berpengaruh signifikan terhadap harga saham

\section{METODE PENELITIAN}

Lokasi penelitian ini dilakukan pada Perusahaan Sektor Properti dan Real Estate yang terdaftar di Bursa Efek Indonesia (BEI). Pemilihan pada perusahaan Properti dan Real Estate sebagai lokasi penelitian didasarkan pada pertimbangan bahwa harga properti yang semakin meningkat setiap tahunnya akan meningkatkan peluang keuntungan bagi investor yang menginvestasikan dananya dalam bisnis properti, namun pada kenyataan harga saham pada sektor properti cenderung menurun.

Populasi yang digunakan dalam penelitian ini adalah 63 Perusahaan Properti dan Real Estate yang terdaftar di Bursa Efek Indonesia (BEI) selama periode 2016-2018. Teknik penentuan sampel yang digunakan dalam penelitian ini adalah purposive sampling. Kriteria yang digunakan untuk menentukan jumlah sampel yaitu Perusahaan Properti dan Real Estate yang terdaftar secara kontinu, mempublikasikan laporan keuangan secara lengkap dan menghasilkan laba selama periode pengamatan yaitu dari tahun 2016-2018 di Bursa Efek Indonesia (BEI).

Data dikumpulkan dengan cara mengamati serta mencatat laporan keuangan yang diperlukan untuk memenuhi penelitian yang akan diteliti. Penelitian ini melakukan pengamatan pada data yang bersumber dari laporan keuangan perusahaan Properti dan Real Estate yang terdaftar di Bursa Efek Indonesia pada 
periode pengamatan tahun 2016-2018 yang diperoleh dari website Bursa Efek Indonesia (www.idx.co.id).

Analisis regresi linier berganda digunakan dengan tujuan untuk mengetahui pengaruh variabel bebas terhadap variabel terikat atas perubahan dari setiap peningkatan atau penurunan variabel bebas yang akan mempengaruhi variabel terikat. Model regresi linier berganda dapat dilihat pada persamaan regresi berikut (Utama, 2016:77):

$$
\mathrm{Y}=\mathrm{a}+\mathrm{b}_{1} \mathrm{X}_{1}+\mathrm{b}_{2} \mathrm{X}_{2}+\mathrm{b}_{3} \mathrm{X}_{3}+\mathrm{b}_{3} \mathrm{X}_{3}+\mathrm{e}
$$

Keterangan :

\begin{tabular}{|c|c|}
\hline Y & = Harga Saham \\
\hline & $=$ Konstanta \\
\hline $\mathrm{b}_{1}, \mathrm{~b}_{2}, \mathrm{~b}_{3}, \mathrm{~b}_{4}$ & $=$ Koefisien regresi \\
\hline $\mathrm{X}_{1}$ & $=$ Total Assets Turnover $(\mathrm{TAT})$ \\
\hline $\mathrm{X}_{2}$ & $=$ Current Ratio $(\mathrm{CR})$ \\
\hline$X_{3}$ & $=$ Return On Assets (ROA) \\
\hline$X_{4}$ & $=$ Price Earning Ratio $(\mathrm{PER})$ \\
\hline & $=$ Kesalahan Residual (error) \\
\hline
\end{tabular}

\section{HASIL DAN PEMBAHASAN}

Penelitian ini bertujuan untuk mengetahui Pengaruh Total Asset Turnover, Current Ratio, Return On Asset, dan Price Earning Ratio terhadap Harga Saham pada Perusahaan Properti dan Real Estate di Bursa Efek Indonesia periode tahun 2016 hingga tahun 2018. Berdasarkan laporan keuangan tahunan, diperoleh hasil analisis statistik deskriptif sebagai berikut:

Tabel 2.

Hasil Analisis Statistik Deskriptif

\begin{tabular}{lcrrrr}
\hline & N & Minimum & Maximum & \multicolumn{1}{c}{ Mean } & Std. Deviation \\
\hline Harga_Saham & 108 & 50 & 36500 & 1988,630 & 5116,410 \\
$T A T$ & 108 & 0,012 & 0,528 & 0,196 & 0,102 \\
$C R$ & 108 & 39,351 & 1276,858 & 282,943 & 228,820 \\
$R O A$ & 108 & 0,003 & 35,890 & 5,590 & 5,524 \\
PER & 108 & 0,462 & 52989,716 & 698,264 & 5195,325 \\
Valid N (listwise) & 108 & & & & \\
\hline Sumber: Data diolah, 2019 & & &
\end{tabular}

Tabel 2. menunjukkan terdapat 108 data yang dianalisis yang diperoleh dari jumlah sampel sebanyak 36 perusahaan dikalikan dengan periode penelitian dari tahun 2016 hingga tahun 2018 yaitu selama 3 tahun. Tabel tersebut juga menjelaskan nilai minimum, nilai maksimum, nilai rata-rata dan standar deviasi dari masing-masing variabel yang digunakan dalam penelitian ini.

Hasil statistik deskriptif pada Tabel 2 menunjukkan bahwa nilai minimum Harga saham sebesar 50 rupiah dan nilai maksimum sebesar 36.500 rupiah. Angka tersebut menunjukkan bahwa besarnya harga saham penelitian ini berkisar antara 50 rupiah sampai 36.500 rupiah dengan rata-rata (mean) 1988,63 rupiah pada standar deviasi sebesar 5116,410 rupiah. Harga saham terendah pada Gading 
Development Tbk. tahun 2016 yaitu 50 rupiah, sedangkan harga saham tertinggi pada Metropolitan Kentjana Tbk. tahun 2017 yaitu 36.500 rupiah.

Hasil uji statistik deskriptif pada Tabel 2. menunjukkan nilai minimum TAT sebesar 0,012 kali dan nilai maksimum sebesar 0,528 kali. Hal ini menunjukkan bahwa besarnya nilai TAT pada sampel penelitian ini berkisar antara 0,012 kali sampai 0,528 kali dengan rata-rata (mean) 0,196 kali pada standar deviasi sebesar 0,102 kali. Nilai TAT terendah pada Greenwood Sejahtera Tbk. tahun 2017 yaitu 0,012 kali, sedangkan nilai TAT tertinggi pada Surya Semesta Internusa Tbk. tahun 2016 yaitu 0,528 kali.

Hasil statistik deskriptif pada Tabel 2. menunjukkan bahwa nilai minimum $C R$ sebesar 39,351 persen dan nilai maksimum sebesar 1276,858 persen. Hal ini menunjukkan bahwa besarnya nilai $C R$ pada sampel penelitian ini berkisar antara 39,351 persen sampai 1276,858 persen dengan rata-rata (mean) 282,943 persen pada standar deviasi sebesar 228,820 persen. Nilai $C R$ terendah pada Duta Anggada Realty Tbk. tahun 2018 yaitu 39,351 persen, sedangkan nilai $C R$ tertinggi pada Puradelta Lestari Tbk. tahun 2018 yaitu 1276,858 persen.

Hasil statistik deskriptif pada Tabel 2. menunjukkan bahwa nilai minimum $R O A$ sebesar 0,003 persen dan nilai maksimum sebesar 35,890 persen. Hal ini menunjukkan bahwa besarnya nilai $R O A$ pada sampel penelitian ini berkisar antara 0,003 persen sampai 35,890 persen dengan rata-rata (mean) 5,590 persen pada standar deviasi sebesar 5,524 persen. Nilai ROA terendah pada Pikko Land Development Tbk. tahun 2018 yaitu 0,003 persen, sedangkan nilai ROA tertinggi pada Fortune Mate Indonesia Tbk. tahun 2016 yaitu 35,890 persen.

Hasil statistik deskriptif pada Tabel 2. menunjukkan bahwa nilai minimum PER sebesar 0,462 kali dan nilai maksimum sebesar 52989,716 kali. Hal ini menunjukkan bahwa besarnya nilai $P E R$ pada sampel penelitian ini berkisar antara 0,462 kali sampai 52989,716 kali dengan rata-rata (mean) 698,264 kali pada standar deviasi 5195,325 kali. Nilai PER terendah pada Lippo Cikarang Tbk. tahun 2018 yaitu 0,462 kali, sedangkan nilai PER tertinggi pada Pikko Land Development Tbk. tahun 2018 yaittu 52989,716 kali.

Uji normalitas merupakan pengujian yang dilakukan untuk mengetahui apakah variabel yang digunakan dalam sebuah penelitian memiliki distribusi yang normal atau tidak. Model regresi yang baik adalah memiliki distribusi data yang normal atau mendekati normal. Ghozali (2016:85) menyatakan bahwa cara yang digunakan untuk menguji apakah data variabel berdistribusi normal atau tidak, yaitu dengan menggunakan uji statistik. Penelitian ini menggunakan uji statistik yaitu Kolmogorov-Smirnov (K-S). Adapun hasil uji normalitas dari penelitian ini disajikan pada Tabel 3. sebagai berikut.

Tabel 3.

Hasil Uji Normalitas (One Sample Kolmogorov-Smirnov Test)

\begin{tabular}{lll}
\hline & & Unstandardized Residual \\
\hline $\mathrm{N}$ & 108 & \\
Kolmogorov-Smirnov $\mathrm{Z}$ & 0,74 & \\
Asymp. Sig. (2-tailed) & 0,178 & \\
\hline
\end{tabular}

Sumber: Data diolah, 2019 
Data akan dikatakan berdistribusi normal apabila Asymp Sig (2-tailed) lebih besar dari level of significant $(\alpha)=0,05$ atau 5\%. Berdasarkan Tabel 4.2, nilai Asymp Sig (2-tailed) dari model persamaan yang diuji yaitu sebesar 0,178 yang lebih besar dari tingkat signifikansi $(0,05)$. Hasil tersebut menunjukkan bahwa data berdistribusi normal.

Tujuan dari uji autokorelasi adalah untuk menguji apakah pada suatu model regresi linier terdapat korelasi antara kesalahan pengganggu pada periode $t$ (saat ini) dengan kesalahan pengganggu pada periode t-1 (sebelumnya). Apabila suatu model regresi mengandung gejala autokorelasi maka model tersebut dapat memberikan hasil prediksi yang menyimpang. Besaran autokorelasi dapat diketahui menggunakan besaran Durbin-Watson pada output pengujian. Hasil tes Durbin-Watson tersebut dibandingkan dengan nilai pada tabel Durbin-Watson menggunakan tingkat keyakinan 95\%. Ketentuan $\mathrm{dU}<\mathrm{d}<(4-\mathrm{dU})$ menyatakan bahwa tidak terdapat gejala autokorelasi pada suatu model regresi linier. Penelitian ini menggunakan $\mathrm{N}=108$ dan $\mathrm{K}$ (variabel bebas) $=4$, maka diperoleh nilai $\mathrm{dU}=1,763$ dan $4-\mathrm{dU}=2,236$, hasil uji autokorelasi dapat dilihat pada Tabel 4 di bawah

Tabel 4.

Hasil Uji Autokorelasi

\begin{tabular}{lccccc}
\hline Model & R & R Square & $\begin{array}{c}\text { Adjusted R } \\
\text { Square }\end{array}$ & $\begin{array}{c}\text { Std. Error of the } \\
\text { Estimate }\end{array}$ & Durbin-Watson \\
\hline 1 & $0,694^{\mathrm{a}}$ & 0,482 & 0,462 & 1,060 & 2,058 \\
\hline Sumber: Data diolah, 2019 & & & & & \\
\hline
\end{tabular}

Berdasarkan Tabel 4. nilai Durbin-Watson sebesar 2,058 dengan jumlah sampel 108 dan jumlah variabel bebas 4 , maka nilai $\mathrm{dU}=1,763$ dan 4-dU $=$ 2,236 . Hal tersebut menunjukkan bahwa nilai Durbin Watson berada diantara dU dan 4-dU yang berarti tidak terdapatnya gejala autokorelasi.

Tabel 5.

Hasil Uji Durbin-Watson

\begin{tabular}{ccc}
\hline & Durbin - Watson & Batas atas \\
\hline$(\mathrm{dU})=1,763$ & 2,058 & $(4-\mathrm{dU})=2,236$ \\
\hline Sumber: & &
\end{tabular}

Sumber: Data diolah, 2019

Uji multikolinearitas bertujuan untuk menguji apakah model regresi ditemukan adanya korelasi antara variabel bebas. Multikolinearitas dapat dilihat dari nilai tolerance maupun dari nilai variance influence factor (VIF). Jika nilai tolerance lebih besar dari 0,1 atau VIF kurang dari 10 maka dapat dikatakan model telah bebas dari masalah multikolinearitas. Adapun hasil pengujian multikolinearitas dari penelitian ini disajikan pada Tabel 6. sebagai berikut.

Berdasarkan hasil uji multikolinearitas pada Tabel 6. dapat dilihat bahwa tidak terdapat nilai tolerance yang lebih besar dari 0.10 pada variabel $T A T, C R$, $R O A$, dan PER. Nilai VIF dari masing-masing variabel bebas menunjukkan angka yang lebih besar dari 10. Hasil tersebut menunjukkan bahwa data yang digunakan tidak mengandung gejala multikolinearitas. 
Tabel 6.

Hasil Uji Multikolinearitas

\begin{tabular}{clccc}
\hline Model & Variabel & Tolerance & VIF & Keterangan \\
\hline 1 & TAT & 0,694 & 1,440 & Bebas Multikolinearitas \\
& $C R$ & 0,977 & 1,023 & Bebas Multikolinearitas \\
& $R O A$ & 0,286 & 3,052 & Bebas Multikolinearitas \\
& $P E R$ & 0,323 & 3,098 & Bebas Multikolinearitas \\
\hline
\end{tabular}

Sumber: Data diolah, 2019

Uji heteroskedastisitas bertujuan menguji apakah dalam model penelitian terjadi ketidaksamaan varian pada residual dari satu pengamatan ke pengamatan lainnya. Uji heteroskedastisitas dalam penelitian ini dilakukan dengan cara meregresi nilai absolute residual sebagai variabel terikat dengan variabel bebas. Suatu model regresi akan dikatakan bebas dari heteroskedastisitas apabila signifikansi $\mathrm{t}$ tiap variabel bebas di atas 0,05. Adapun hasil pengujian heteroskedastisitas dari penelitian ini disajikan pada Tabel 7. sebagai berikut.

Tabel 7.

Hasil Uji Heteroskedastisitas

\begin{tabular}{clcc}
\hline Model & Variabel & Signifikansi & Keterangan \\
\hline & $T A T$ & 0,564 & Bebas Heteroskedastisitas \\
& $C R$ & 0,060 & Bebas Heteroskedastisitas \\
& $R O A$ & 0,300 & Bebas Heteroskedastisitas \\
& $P E R$ & 0,211 & Bebas Heteroskedastisitas \\
\hline
\end{tabular}

Sumber: Data diolah, 2019

Berdasarkan hasil uji heteroskedastisitas pada Tabel 7, dapat diketahui nilai signifikansi dari variabel $T A T$ sebesar 0,564 , variabel $C R$ sebesar 0,060 , variabel $R O A$ sebesar 0,300, dan variabel PER sebesar 0,211. Nilai signifikansi dari masing-masing variabel independen terhadap variabel absolute residual berada di atas 0,05 maka dapat dikatakan bahwa data yang digunakan pada penelitian ini tidak terdapat masalah heteroskedastisitas.

Model analisis yang digunakan pada penelitian ini adalah analisis regresi linier berganda, karena dapat menjelaskan pengaruh variabel bebas terhadap variabel terikat. Tujuan penelitian ini adalah untuk mengetahui pengaruh Total Asset Turnover $\left(\mathrm{X}_{1}\right)$, Current Ratio $\left(\mathrm{X}_{2}\right)$, Return On Asset $\left(\mathrm{X}_{3}\right)$, dan Price Earning Ratio $\left(\mathrm{X}_{4}\right)$ terhadap Harga Saham (Y) pada perusahaan Properti dan Real Estate periode 2016-2018. Adapun hasil pengujian analisis regresi linier berganda dari penelitian ini disajikan pada Tabel 8. sebagai berikut.

Hasil analisis pada Tabel 8. dapat dibuat persamaan regresi linier berganda sebagai berikut:

$$
\mathrm{y}=4,184+0,214 \mathrm{x}_{1}-0,213 \mathrm{x}_{2}+1,099 \mathrm{x}_{3}+0,821 \mathrm{x}_{4}
$$

Keterangan :

$$
\begin{array}{ll}
\mathrm{y} & =\text { Harga Saham } \\
\mathrm{a} & =\text { Konstanta } \\
\mathrm{b}_{1}, \mathrm{~b}_{2}, \mathrm{~b}_{3}, \mathrm{~b}_{4} & =\text { Koefisien regresi } \\
\mathrm{x}_{1} & =\text { Total Assets Turnover (TAT) }
\end{array}
$$




\begin{tabular}{|c|c|}
\hline $\mathrm{X}_{2}$ & $=$ Current Ratio $(C R)$ \\
\hline $\mathrm{X}_{3}$ & $=$ Return On Assets (ROA) \\
\hline $\mathrm{X}_{4}$ & $=$ Price Earning Ratio $(P E R)$ \\
\hline & $=$ Kesalahan Residual (error) \\
\hline
\end{tabular}

Tabel 8.

Hasil Uji Regresi Linier Berganda

\begin{tabular}{|c|c|c|c|c|c|c|c|}
\hline & \multirow[t]{2}{*}{ Model } & \multicolumn{2}{|c|}{$\begin{array}{l}\text { Unstandardized } \\
\text { Coefficients }\end{array}$} & \multirow{2}{*}{$\begin{array}{c}\text { Standardized } \\
\text { Coefficients } \\
\text { Beta } \\
\end{array}$} & \multirow[t]{2}{*}{$\mathbf{t}$} & \multirow[t]{2}{*}{ Sig. } & \multirow[t]{2}{*}{ Hasil Uji } \\
\hline & & B & Std. Error & & & & \\
\hline \multirow[t]{5}{*}{1} & (Constant) & 4,184 & 0,948 & & 4,415 & 0,000 & \\
\hline & $T A T$ & 0,214 & 0,168 & 0,108 & 1,275 & 0,205 & Ditolak \\
\hline & $C R$ & $-0,213$ & 0,141 & $-0,108$ & $-1,510$ & 0,134 & Ditolak \\
\hline & $R O A$ & 1,099 & 0,130 & 1,118 & 8,425 & 0,000 & Diterima \\
\hline & PER & 0,821 & 0,107 & 0,957 & 7,671 & 0,000 & Diterima \\
\hline
\end{tabular}

Nilai koefisien beta TAT sebesar 0,214 mempunyai nilai positif yang menunjukkan adanya hubungan searah, apabila TAT naik sebesar 1 kali, maka harga saham meningkat sebesar 0,214 rupiah dengan syarat variabel bebas lainnya konstan atau sama dengan nol.

Nilai koefisien beta $C R$ sebesar 0,213 memiliki nilai negatif yang menunjukkan adanya hubungan yang berlawanan, apabila $C R$ naik sebesar 1 persen, maka harga saham menurun sebesar 0,213 rupiah dengan syarat variabel bebas lainnya konstan atau sama dengan nol. Nilai koefisien beta ROA sebesar 1,099 memiliki nilai positif yang menunjukkan adanya hubungan yang searah, apabila $R O A$ naik sebesar 1 persen, maka harga saham meningkat sebesar 1,099 rupiah dengan syarat variabel bebas lainnya konstan atau sama dengan nol.

Nilai koefisien beta PER sebesar 0,821 memiliki nilai yang positif menunjukkan adanya hubungan yang searah, apabila $P E R$ naik sebesar 1 kali, maka harga saham meningkat sebesar 0,821 rupiah dengan syarat variabel bebas lainnya konstan atau sama dengan nol.

Koefisien determinasi dalam penelitian ini dilihat melalui Adjusted $R^{2}$. Hasil koefisien determinasi $R^{2}$ dapat dilihat pada Tabel 9.

Tabel 9.

Hasil Uji Koefisien Determinasi (Uji $\mathbf{R}^{2}$ )

\begin{tabular}{lrrrr}
\hline Model & R & R Square & Adjusted R Square & $\begin{array}{c}\text { Std. Error of the } \\
\text { Estimate }\end{array}$ \\
\hline 1 & $0,694^{\mathrm{a}}$ & 0,482 & 0,462 & 1,06048 \\
\hline
\end{tabular}

Sumber: Data diolah, 2019

Berdasarkan Tabel 9, dapat dilihat nilai $R^{2}$ sebesar 0,482 hal ini berarti 48,2 persen variasi harga saham dapat dijelaskan oleh variasi TAT, CR, ROA, dan PER, sedangkan sisanya sebesar 51,8 persen dipengaruhi oleh variabel lain diluar dari model penelitian.

. Hasil uji signifikansi simultan (Uji F) dapat dilihat pada Tabel 10. 
Tabel 10.

Hasil Uji Signifikansi Simultan (Uji Statistik F)

\begin{tabular}{llccccc}
\hline Model & & Sum of Squares & df & Mean Square & F & Sig. \\
\hline \multirow{4}{*}{1} & Regression & 107,841 & 4 & 26,960 & 23,973 & $0,000^{\mathrm{b}}$ \\
& Residual & 115,836 & 103 & 1,125 & & \\
& Total & 223,677 & 107 & & & \\
\hline
\end{tabular}

Sumber: Data diolah, 2019

Berdasarkan hasil regresi pada Tabel 10, menunjukkan bahwa variabel independen berpengaruh serempak (simultan) terhadap variabel dependen. Tingkat signifikansi (Sig. F) sebesar 0,000 lebih kecil dari nilai $\alpha=0,05$. Hasil tersebut menunjukkan bahwa seluruh variabel independen (TAT, CR, ROA, dan $P E R)$ dapat memprediksi atau menjelaskan fenomena harga saham pada perusahaan Properti dan Real Estate yang terdaftar di Bursa Efek Indonesia periode 2016-2018, sehingga dapat dikatakan bahwa model dalam penelitian ini dikatakan layak untuk diteliti.

Uji statistik t dilakukan untuk mengetahui seberapa jauh pengaruh satu variabel independen secara individual menerangkan variasi variabel dependen. Uji statistik $\mathrm{t}$ dilakukan dengan membandingkan hasil nilai signifiikansi dengan $\alpha=$ 0,05. Apabila tingkat signifikansi t hitung lebih kecil daripada 0,05 maka dapat dikatakan variabel bebas tersebut secara individual memengaruhi variabel terikat, begitu pula sebaliknya. Hasil Uji statistik t dapat dilihat pada Tabel 11.

Tabel 11.

Hasil Uji Signifikansi Koefisien Regresi Secara Individual (t-test)

\begin{tabular}{|c|c|c|c|c|c|c|}
\hline \multirow{2}{*}{\multicolumn{2}{|c|}{ Model }} & \multicolumn{2}{|c|}{$\begin{array}{l}\text { Unstandardized } \\
\text { Coefficients }\end{array}$} & \multirow{2}{*}{$\begin{array}{c}\text { Standardized } \\
\text { Coefficients } \\
\text { Beta }\end{array}$} & \multirow[t]{2}{*}{$\mathbf{t}$} & \multirow[t]{2}{*}{ Sig. } \\
\hline & & B & Std. Error & & & \\
\hline \multirow{5}{*}{1} & (Constant) & 4,184 & 0,948 & & 4,415 & 0,000 \\
\hline & $T A T$ & 0,214 & 0,168 & 0,108 & 1,275 & 0,205 \\
\hline & $C R$ & $-0,213$ & 0,141 & $-0,108$ & $-1,510$ & 0,134 \\
\hline & $R O A$ & 1,099 & 0,130 & 1,118 & 8,425 & 0,000 \\
\hline & $P E R$ & 0,821 & 0,107 & 0,957 & 7,671 & 0,000 \\
\hline
\end{tabular}

Berdasarkan Tabel 11. diperoleh nilai signifikansi t dari variabel TAT sebesar 0,205 lebih besar dari $\alpha=0,05$, ini berarti bahwa TAT berpengaruh tidak signifikan terhadap Harga Saham perusahaan Properti dan Real Estate periode tahun 2016-2018 dengan arah yang positif sebesar 0,214 dengan asumsi variabel lain konstan.

Berdasarkan Tabel 11 diperoleh nilai signifikansi t dari variabel $C R$ sebesar 0,134 lebih besar dari $\alpha=0,05$, ini berarti bahwa $C R$ berpengaruh negatif dan tidak signifikan terhadap Harga Saham perusahaan Properti dan Real Estate periode tahun 2016-2018 dengan arah yang negatif sebesar 0,213 dengan asumsi variabel lain konstan.

Berdasarkan Tabel 11. diperoleh nilai signifikansi t dari variabel $R O A$ sebesar 0,000 lebih kecil dari $\alpha=0,05$, ini berarti bahwa $R O A$ berpengaruh positif dan signifikan terhadap Harga Saham perusahaan Properti dan Real Estate periode 
tahun 2016-2018 dengan arah yang positif sebesar 1,099 dengan asumsi variabel lain konstan.

Berdasarkan Tabel 11. diperoleh nilai signifikansi t dari variabel PER sebesar 0,000 lebih kecil dari $\alpha=0,05$, ini berarti bahwa PER berpengaruh positif dan signifikan terhadap Harga Saham perusahaan Properti dan Real Estate periode tahun 2016-2018 dengan arah yang positif sebesar 0,821 dengan asumsi variabel lain konstan.

Nilai koefisien regresi menunjukkan bahwa TAT mempengaruhi harga saham sebesar 0,108 dengan arah positif pada tingkat signifikansi menunjukkan angka 0,205 dimana angka tersebut lebih besar dari nilai $\alpha 0,05$. Berdasarkan hasil uji tersebut maka TAT berpengaruh tidak signifikan terhadap harga saham perusahaan Properti dan Real Estate di BEI periode tahun 2016-2018.

Berdasarkan teori TAT bahwa semakin tinggi rasio TAT mengindikasikan efektivitas suatu perusahaan semakin baik, sehingga mampu menarik minat investor untuk berinvestasi pada perusahaan tersebut yang akhirnya meningkatkan harga saham perusahaan. Hasil penelitian pada variabel TAT ini sesuai dengan teori yang dikemukakan tersebut. Pengaruh yang tidak signifikan dari TAT terhadap Harga Saham disebabkan oleh total aset perusahaan melebihi penjualan yang dihasilkan perusahaan. Penjualan yang rendah mengakibatkan laba bersih perusahaan juga menurun. Rendahnya laba perusahaan akan mengurangi minat investor untuk menanamkan modalnya pada suatu perusahaan. Fenomena tersebut menunjukkan bahwa investor tidak menggunakan pertimbangan perputaran total aset perusahaan dalam keputusan investasinya sehingga menyebabkan harga saham mengalami penurunan.

Hasil penelitian ini mendukung oleh penelitian Azhari dkk. (2016) serta Ermaya \& Nugraha (2018) yang menyatakan bahwa TAT tidak berpengaruh terhadap Harga Saham. Nugraha \& Sudaryanto (2016) juga menemukan hasil yang sama dalam penelitiannya pada Perusahaan Industri Dasar dan Kimia yang terdaftar di BEI yang menemukan bahwa TAT tidak memiliki pengaruh yang signifikan terhadap harga saham perusahaan. Firmansyah (2017) menemukan hasil yang sama dalam penelitiannya pada perusahaan manufaktur yang terdaftar di BEI periode 2010-2014 yaitu bahwa TAT tidak berpengaruh terhadap harga saham.

Nilai koefisien regresi menunjukkan bahwa $C R$ mempengaruhi harga saham sebesar 0,108 dengan arah negatif pada tingkat signifikansi menunjukkan angka 0,134 yang lebih besar dari nilai $\alpha 0,05$. Berdasarkan hasil uji tersebut maka $C R$ berpengaruh negatif dan tidak signifikan terhadap harga saham perusahaan Properti dan Real Estate di BEI periode tahun 2016-2018.

Hasil penelitian ini bertentangan dengan teori $C R$ yang mengatakan bahwa tingginya $C R$ akan menarik minat investor untuk berinvestasi sehingga akan meningkatkan permintaan akan saham perusahaan tersebut dan akhirnya akan meningkatkan harga sahamnya. Pengaruh yang negatif dan tidak signifikan dari $C R$ terhadap Harga Saham disebabkan karena nilai $C R$ yang tinggi menunjukkan adanya kelebihan aset lancar sehingga akan berpengaruh tidak baik terhadap kinerja perusahaan. Terlalu tingginya nilai $C R$ perusahaan mengindikasikan adanya dana mengganggur (idle fund) yang tinggi pula. Hal tersebut 
mencerminkan perusahaan kurang mampu dalam mengelola aset lancarnya sehingga dapat menimbulkan kerugian. Ketidakmampuan perusahaan dalam memaksimalkan penggunaan aset lancar dapat mengurangi laba perusahaan, sehingga dapat dikatakan kemampuan perusahaan untuk membayar hutang jangka pendeknya dengan aktiva lancar bukan merupakan pertimbangan bagi investor dalam berinvestasi karena $C R$ tidak secara langsung akan berpengaruh pada pengembalian saham yang berupa dividen atau capital gain bagi investor. Berdasarkan hal tersebut maka permintaan investor terhadap suatu saham akan semakin berkurang yang akan berujung pada menurunnya harga saham perusahaan.

Hasil penelitian ini mendukung penelitian dari Sitorus \& Elinarty (2017) serta Pratama dkk. (2019) dalam penelitiannya yang menemukan bahwa $C R$ memiliki pengaruh yang negatif terhadap harga saham perusahaan. Nursiam \& Rahayu (2019) dalam penelitiannya menemukan hal yang sama bahwa $C R$ tidak berpengaruh terhadap harga saham perusahaan indeks LQ45 di BEI.

Nilai koefisien regresi menunjukkan bahwa ROA mempengaruhi Harga Saham sebesar 1,118 dengan arah positif pada tingkat signifikansi menunjukkan angka 0,000 dimana lebih kecil dari nilai $\alpha 0,05$. Berdasarkan hasil uji tersebut maka $R O A$ berpengaruh signifikan dengan arah positif terhadap Harga Saham Perusahaan Properti dan Real Estate di BEI periode tahun 2016-2018.

Hasil penelitian ini sesuai dengan teori $R O A$ yang menyatakan $R O A$ yang positif atau yang semakin besar menunjukkan bahwa pengelolaan atau manajemen aset yang dilakukan oleh perusahaan telah efisien, sehingga aset perusahaan mampu menghasilkan laba yang semakin besar. Kondisi laba yang semakin besar menarik minat investor sehingga dapat meningkatkan permintaan saham, yang nantinya akan secara langsung meningkatkan harga saham perusahaan. Pengaruh yang positif dan signifikan dari ROA terhadap Harga Saham disebabkan karena investor tertarik dengan peningkatan profitabilitas perusahaan yang diukur dari rasio $R O A$. Nilai $R O A$ suatu perusahaan selalu dapat menggambarkan harga saham perusahaan di masa yang akan datang. Semakin tingginya keuntungan yang dapat dihasilkan oleh perusahaan maka kemampuan aset perusahaan untuk menghasilkan laba bersih, yang dapat memberikan informasi relevan dalam pengambilan keputusan investasi pemegang saham.

Hasil penelitian ini mendukung penelitian yang dilakukan oleh Manoppo (2015) dan Nur'aidawati (2018) yang menyatakan ROA berpengaruh positif dan signifikan terhadap harga saham. Dadrasmoghadam \& Akbari (2015) melakukan penelitian pada perusahaan yang terdaftar di bursa saham Iran dan menemukan adanya pengaruh $R O A$ yang positif dan signifikan terhadap harga saham.

Nilai koefisien regresi menunjukkan bahwa PER mempengaruhi Harga Saham sebesar 0,957 dengan arah positif pada tingkat signifikasi menunjukkan angka 0,000 dimana lebih kecil dari nilai $\alpha 0,05$. Berdasarkan hasil uji tersebut maka $P E R$ berpengaruh positif dan signifikan terhadap Harga Saham Perusahaan Properti dan Real Estate di BEI periode tahun 2016-2018.

Hasil penelitian ini sesuai dengan teori $P E R$ yang menyatakan bahwa nilai rasio $P E R$ yang semakin tinggi menunjukkan semakin tinggi pengakuan pasar terhadap posisi keuangan perusahaan dan menunjukkan semakin mahal harga 
saham perusahaan tersebut. Pengaruh yang positif dan signifikan dari $P E R$ terhadap Harga Saham disebabkan karena semakin tinggi nilai $P E R$ maka harga saham dinilai semakin tinggi oleh investor, sehingga $P E R$ yang semakin tinggi juga menunjukkan semakin mahal saham tersebut terhadap pendapatannya. Semakin tinggi PER yang dibayar investor untuk earning akan memberikan informasi yang positif bagi investor dalam berinvestasi sehingga akan menarik minat investor untuk menanamkan modalnya pada perusahaan tersebut.

Hasil tersebut mendukung penelitian yang dilakukan oleh Bassey (2016) dan Sharif et al (2015) yang menyatakan bahwa PER berpengaruh positif dan signifikan terhadap harga saham. Penelitian Rahmadewi \& Abundanti (2018) juga menemukan hasil bahwa PER secara signifikan berpengaruh positif terhadap harga saham.

Hasil penelitian ini memberikan tambahan informasi mengenai bagaimana $T A T, C R, R O A$, dan PER terhadap Harga Saham pada perusahaan Properti dan Real Estate di Bursa Efek Indonesia periode 2016-2018. Penelitian ini memberikan bukti empiris bahwa ROA dan PER berpengaruh positif dan signifikan terhadap harga saham yang berarti investor memperhatikan $R O A$ dan $P E R$ dalam melakukan investasi.

Analisis fundamental perusahaan digunakan untuk mengidentifikasi prospek perusahaan melalui analisis faktor-faktor yang mempengaruhi agar dapat diperkirakan harga saham di masa yang akan datang, dimana nilai $R O A$ yang semakin tinggi akan menarik minat investor untuk berinvestasi pada perusahaan dikarenakan kemampuan perusahaan dalam menghasilkan laba semakin meningkat. Begitu pula dengan PER, semakin tinggi PER maka akan semakin tinggi juga minat investor dalam menanamkan modal pada perusahaan, sehingga harga saham juga akan ikut naik.

Hasil dari penelitian ini diharapkan dapat digunakan sebagai gambaran, bahan pertimbangan dan masukan bagi perusahaan Properti dan Real Estate untuk meningkatkan harga saham perusahaannya. Penelitian ini pula diharapkan dapat memberikan pertimbangan bagi investor dan calon investor dalam mengambil keputusan berinvestasi sebelum menanamkan modalnya di perusahaan Properti dan Real Estate tersebut.

\section{SIMPULAN}

Total Asset Turnover berpengaruh positif dan tidak signifikan terhadap Harga Saham Perusahaan Properti dan Real Estate di BEI periode 2016-2018. Pengaruh yang tidak signifikan dari Total Asset Turnover terhadap Harga Saham menunjukkan bahwa dalam berinvestasi investor tidak memperhatikan rasio aktivitas yang diukur Total Asset Turnover pada perusahaan Properti dan Real Estate di BEI periode 2016-2018. Current Ratio berpengaruh negatif dan tidak signifikan terhadap Harga Saham Perusahaan Properti dan Real Estate di BEI periode 2016-2018. Pengaruh yang tidak signifikan dari Current Ratio terhadap Harga Saham memberikan arti bahwa investor dalam berinvestasi tidak memperhatikan likuiditas yang diukur Current Ratio pada perusahaan Properti dan Real Estate di BEI periode 2016-2018. Return On Asset berpengaruh positif 
dan signifikan terhadap Harga Saham Perusahaan Properti dan Real Estate di BEI periode 2016-2018. Pengaruh yang signifikan dari Return On Asset terhadap Harga Saham menunjukkan bahwa investor memperhatikan kemampuan aset perusahaan untuk menghasilkan laba bersih karena investor mengharapkan adanya peningkatan laba pada perusahaan Properti dan Real Estate di BEI periode 20162018.

Price Earning Ratio berpengaruh positif dan signifikan terhadap Harga Saham Perusahaan Properti dan Real Estate di BEI periode 2016-2018. Pengaruh yang signifikan dari Price Earning Ratio terhadap Harga Saham memberikan arti bahwa semakin tinggi harga yang dibayar investor untuk earning akan memberikan informasi yang positif bagi investor dalam berinvestasi pada perusahaan Properti dan Real Estate di BEI periode 2016-2018.

Bagi penelitian selanjutnya disarankan untuk mempertimbangkan faktorfaktor lain seperti rasio inventory turnover, rasio cepat, rasio net profit margin, dan earning per share yang dapat mempengaruhi harga saham perusahaan. Penelitian ini diharapkan dapat dijadikan motivasi bagi emiten untuk meningkatkan harga saham perusahaannya dengan memperhatikan nilai-nilai yang menyangkut rasio kinerja keuangan terutama rasio $R O A$ dan $P E R$, karena $R O A$ dan $P E R$ berpengaruh positif signifikan terhadap harga saham. Bagi investor, penelitian ini diharapkan dapat dijadikan dasar dalam penilaian kinerja keuangan yang menjadi awal proses transaksi dan proses pengambilan keputusan investasi.

\section{REFERENSI}

Arshad, Z., \& et al. (2015). Determinants of Share Prices of Listed Commercial Banks in Pakistan. IOSR Journal of Economics and Finance (IOSR-JEF), 6(2), 56-64.

Astutik, E. D., \& et al. (2014). The Effect of Fundamental and Technical Variables on Stock Price (Study on Manufacturing Companies Listed in IDX). Journal of Economics, Business, and Accountancy Ventura, 17(3), 345-352.

Astuty, P. (2017). The Influence of Fundamental Factors and Systematic Risk to Stock Prices on Companies Listed in the Indonesian Stock Exchange. European Research Studies Journal, 19(4A), 230-240.

Ayudia, R. (2017). The Impact of Fundamental and Macroeconomic Factors on The Stock Price of Oil Palm Plantation Companies in IDX. Journal of Economics, Business, and Accountancy Ventura, 20(2), 141-148.

Azhari, D. F., \& dkk. (2016). Pengaruh ROE, DER, TATO, dan PER terhadap Harga Saham Perusahaan Properti dan Real Estate yang Go Publik di Bursa Efek Indonesia. Jurnal Administrasi Bisnis, 32(2), 1-5.

Bassey, B. E. (2016). Effect of Corporate Earnings on Stock Price of Selected Oil and Gas Companies in the Nigerian. European Journal of Business and Innovation Research, 4(5), 93-111. 
Brigham, E. F., \& Houston, J. F. (2015). Dasar-dasar Manajemen Keuangan (Edisi 11 C). Jakarta: Salemba Empat.

Dadrasmoghadam, A., \& Akbari, S. M. R. (2015). Relationship between Financial Ratios in the Stock Prices of Agriculture-Related Companies Accepted On the Stock Exchange for Iran. Research Journal of Fisheries and Hydrobiology, 10(9), 586-591.

Dewi, A. D. I. R., \& Artini, L. G. S. (2016). Pengaruh Suku Bunga SBI, Inflasi, dan Fundamental Perusahaan Terhadap Harga Saham Indeks LQ-45 Di BEI. E-Jurnal Manajemen Fakultas Ekonomi Dan Bisnis Universitas Udayana, 5(4), 2484-2510.

Ermaya, S. K., \& Nugraha. (2018). Pengaruh Current Ratio, Debt To Equity Ratio, Total Assets Turnover dan Earning Per Share Terhadap Harga Saham. Jurnal AKP, 8(1), 51-78.

Fauza, M. S., \& Mustanda, I. K. (2016). Pengaruh Profitabilitas, Earning Per Share (EPS), dan Dividend Payout Ratio (DPR), Terhadap Harga Saham. EJurnal Manajemen Fakultas Ekonomi Dan Bisnis Universitas Udayana, 5(12), 8015-8045.

Firmansyah, M. (2017). Pengaruh Pertumbuhan Perusahaan, Total Asset Turnover, Return On Investment, Earning Per Share Terhadap Harga Saham (Studi Perusahaah Manufaktur Di BEI). Asian Journal of Innovation and Entrepreneurship (AJIE), 2(2), 110-121.

Ghozali, I. (2016). Aplikasi Multivariate dengan Program IBM SPSS 23 (Edisi 8). Semarang: Badan Penerbit Universitas Diponegoro.

Gusni. (2015). Studi Tentang Pentingnya Analisis Fundamental Saham. Jurnal Management \& Bisnis SMART Study \& Management Reasearch, 12(2), 3744.

Hadi, W., \& Nurhayati. (2018). Analysis of The Effect of Net Profit Margin, Return On Assets and Return On Equity on Stock Price (Case Study on Consumption Industrial Sector Companies Listed in Indonesian Sharia Stock Index at Indonesia Stock Exchange in 2016). The Management Journal of BINANIAGA, 3(2), 81-92.

Hanafi, M. M., \& Halim, A. (2016). Analisis Laporan Keuangan (Edisi Keli). Yogyakarta: UPP STIM YKPN.

Harahap, S. S. (2015). Analisis Kritis Atas Laporan Keuangan (Cetakan Ke). Jakarta: Raja Grafindo Persada.

Hartono, J. (2017). Teori Portofolio dan Analisis Investasi (Edisi Kese). Yogyakarta: BPFE-YOGYAKARTA.

Herawati, A., \& Putra, A. S. (2018). The Influence of Fundamental Analysis on Stock Prices: The Case of Food and Beverage Industries. European Research 
Studies Journal, XXI(3), 316-326.

Idawati, W., \& Wahyudi, A. (2015). Effect of Earning Per Shares (EPS) and Return On Assets (ROA) against Share Price on Coal Mining Company Listed in Indonesia Stock Exchange. Journal of Resources Development and Management, 7, 377-392.

Karjono, A., \& Wijaya. (2017). Analisis Pengaruh ROE, DER, dan TATO terhadap Harga Saham pada perusahaan Manufaktur Sektor Industri Barang Konsumsi yang Terdaftar di Bursa Efek Indonesia Periode 2012-2015. Jurnal Bisnis Dan Manajemen (ESENSI), 20(2), 117-141.

Lestari, I. S. D., \& Suryantini, N. P. S. (2019). Pengaruh CR, DER, ROA, dan PER terhadap Harga Saham Pada Perusahaan Farmasi di BEI. E-Jurnal Manajemen Fakultas Ekonomi Dan Bisnis Universitas Udayana, 8(3), 18441871.

Manoppo, C. P. (2015). The Influence of ROA, ROE, ROS, and EPS on Stock Price. Jurnal EMBA, 3(4), 691-697.

Martha, \& Meilin, L. (2018). Analisis Pengaruh Current Ratio (CR), Debt to Equity Ratio (DER), Return On Assets (ROA), dan Price Earning Ratio (PER) Terhadap Harga Saham pada Perusahaan Sektor Perkebunan yang Terdaftar di Bursa Efek Indonesia Tahun 2010-2016. Jurnal Ilmiah Akuntansi BILANCIA, 2(4), 397-407.

Mogonta, K., \& Pandowo, M. (2016). Analyzing The Effect of Return On Assets, Return On Equity and Earnings Per Share on Market Share Price : A Study Of LQ-45 Mining Companies Listed On Indonesia Stock Exchange. Jurnal EMBA, 4(2), 701-713.

Mulyono, \& et al. (2018). The Effect of Corporate Governance and Firm Performance on Stock Price: An Empirical Study on Indonesia Stock Exchange. Binus Business Review, 9(1), 79-85.

Nugraha, R. D., \& Sudaryanto, B. (2016). Analisis Pengaruh DPR, DER, ROE, Dan TATO Terhadap Harga Saham (Studi Kasus Pada Perusahaan Industri Dasar Dan Kimia Yang Terdaftar Di BEI Periode 2010-2014). Diponegoro Journal of Management, 5(4), 1-12.

Nur'aidawati, S. (2018). Pengaruh Current Ratio (CR), Total Asset Turnover (TATO), Debt to Equity Ratio (DER), dan Return On Asset (ROA) terhadap harga saham dan dampaknya pada nilai perusahaan (Studi Kasus pada Sepuluh Bank Terbesar yang terdaftar di Bursa Efek Indonesia Periode. Jurnal Sekuritas (Saham Ekonomi Keuangan Dan Investasi), 1(3), 70-83.

Nursiam, \& Rahayu, V. S. (2019). The Effect of Company Size, Sales Growth, Current Ratio (CR), Net Profit Margin (NPM), and Return On Equity (ROE) on Stock Prices. Jurnal Manajemen Bisnis, 9(1), 13-21.

Pratama, C. A., \& dkk. (2019). Pengaruh Return On Equity (ROE), Earning Per 
Share (EPS), Current Ratio (CR) dan Debt To Equity Ratio (DER) Terhadap Harga Saham (Studi pada Perusahaan Jakarta Islamic Index yang Terdaftar di Bursa Efek Indonesia Tahun 2014-2017). Jurnal Administrasi Bisnis, 66(1), $10-17$.

Prayogo, K. H., \& Lestari, E. P. (2018). The Determinant of Stock Price at The Banking Sub-Sector Company in Indonesia Stock Exchange. International Journal of Trade, Economics and Finance, 9(6), 231-237.

Purnama, I. B. A., \& Purbawangsa, I. B. A. (2017). Pengaruh Kinerja Keuangan dan Variabel Makro Ekonomi terhadap Harga Saham Perusahaan Pertambangan. E-Jurnal Manajemen Fakultas Ekonomi Dan Bisnis Universitas Udayana, 6(4), 1729-1760.

Rahayu, N. M. P. S., \& Dana, I. M. (2016). Pengaruh EVA, MVA, dan Likuiditas Terhadap Harga Saham pada Perusahaan Food and Beverages. E-Jurnal Manajemen Fakultas Ekonomi Dan Bisnis Universitas Udayana, 5(1), 443469.

Rahmadewi, P. W., \& Abundanti, N. (2018). Pengaruh EPS, PER, CR, dan ROA terhadap Harga Saham di BEI. E-Jurnal Manajemen Fakultas Ekonomi Dan Bisnis Universitas Udayana, 7(4), 2106-2133.

Rani, K. S., \& Diantini, N. N. A. (2015). Pengaruh Kinerja Keuangan Perusahaan Terhadap Harga Saham LQ45 Di BEI. E-Jurnal Manajemen Fakultas Ekonomi Dan Bisnis Universitas Udayana, 4(6), 1504-1524.

Sartono, A. (2014). Manajemen Keuangan: Teori dan Aplikasi (Edisi Keem). Yogyakarta: BPFE-YOGYAKARTA.

Sharif, T., \& et al. (2015). Analysis of Factors Affecting Share Prices: The Case of Bahrain Stock Exchange. International Journal of Economics and Finance, 7(3), 207-216.

Sitorus, T., \& Elinarty, S. (2017). The Influence of Liquidity and Profitability Toward the Growth at Stock Price mediated by the Dividends Paid Out (Case in Banks listed in Indonesia Stock Exchange). Journal of Economics, Business, and Accountancy Ventura, 19(3), 377-392.

Tamuntuan, U. (2015). Analysing The Effect Of Return On Equity, Return On Assets and Earnings Per Share Toward Share Price: An Emperical Study Of Food And Beverage Companies Listed On Indonesia Stock Exchange. Jurnal Berkala Ilmiah Efisiensi, 15(5), 446-457.

Tandelilin, E. (2014). Portofolio dan Investasi: Teori dan Aplikasi (Edisi Pert). Yogyakarta: BPFE-YOGYAKARTA.

Utama, S. (2016). Buku Ajar Aplikasi Analisis Kuantitif (Edisi Keen). Denpasar: Sastra Utama.

Warrad, L. H. (2017). The Effect of Marke Valuation Measures on Stock Price: 
Ni Ketut Nadila Suryasari, Pengaruh Tat, $C r .$.

An Empirical Investigation on Jordanian Banks. International Journal of Business and Social Science, 8(3), 67-74.

Wiagustini, N. L. P. (2014). Dasar-Dasar Manajemen Keuangan. Denpasar: Udayana University Press.

Zulkarnaen, A. H., \& et al. (2016). Analysis of Fundamental and Technical Factors to Stock Price on Residential Property Sector Companies Listed in Indonesia Stock Exchange. International Journal of Scientific and Research Publications, 6(12), 315-319. 